A Mixed Frigoribacterium faeni and Lactococcus garvieae Infection in Cultured Rainbow Trout (O. mykiss)

\author{
Tülay AKAYLI ${ }^{1}$, Özgür ÇANAK ${ }^{\wedge}$, Remziye Eda YARDIMCI ${ }^{1}$, Çiğgdem ÜRKÜ1, Dilek ÖKMEN² \\ 1'Istanbul University, Faculty of Aquatic Sciences, Department of Fish Diseases, Ordu Cad. No:8 Laleli İstanbul Turkey, ${ }^{2}$ İstanbul University \\ Institute of Science. \\ ${ }^{1}$ https://orcid.org/0000-0003-2375-2224, ${ }^{2}$ https://orcid.org/0000-0001-6194-0096, ${ }^{3}$ https://orcid.org/0000-0001-7737-8739, \\ ${ }^{4}$ https://orcid.org/0000-0003-0381-9321, ${ }^{5} \mathrm{https}: / / o r c i d . o r g / 0000-0003-3267-466 \mathrm{X}$ \\ $\square$ : ocanak@istanbul.edu.tr
}

\begin{abstract}
The aim of this study was to diagnose the bacterial pathogens of moribund rainbow trout (Oncorhynchus mykiss) reared in a dam-lake cage farm located in the Black Sea Region of Turkey and to determine their antibiotic susceptibility and histopathological effects by using routine bacteriological, histopathological and molecular methods. Besides possibility of the use of two probiotics against these pathogens for the prevention of further infections was investigated. In this study, a mixed bacterial infection case caused by Frigoribacterium faeni and Lactococcus garvieae was diagnosed in rainbow trout samples of 100$250 \mathrm{~g}$ with general clinical and histopathological symptoms of bacterial hemorrhagic septicemia. Pathogens were found to be resistant against most of the antibiotics tested and the possibility of the use of Bacillus subtilis as a probiotic to prevent diseases caused by these pathogens was proposed.
\end{abstract}

\section{Kültür Gökkuşağı Alabalıklarında (O. mykiss) Frigoribacterium faeni ve Lactococcus garvieaenin Neden Olduğu Karma Enfeksiyon}

\section{ÖZET}

$\mathrm{Bu}$ çalışmanın amacı, bakteriyolojik ve histopatolojik metotlar ve moleküler yöntemler kullanarak Karadeniz Bölgesi’ndeki bir baraj gölünde yetiştiriciliği yapılan gökkuşağı alabalıklarında (Oncorhynchus mykiss) hastalığa neden olan bakteriyel patojenlerin teşhisini yapmak, antimikrobiyal duyarlılıklarını belirlemek ve histopatolojik etkilerini ortaya koymaktır. İki adet probiyotik bakterinin, bu patojenlerin neden olduğu hastalı̆̆ın önlenmesi amacıyla kullanım olanakları da incelenmiştir. Bu çalışmada kapsamında incelenen 100-250 g ağırlı̆̆ındaki hasta balıklardan Frigoribacterium faeni ve Lactococcus garvieae'nin neden olduğu genel klinik ve histopatolojik bakteriyel hemorajik septisemi bulguları ile seyreden karma bir enfeksiyon olgusu teşhis edilmiştir. İzole edilen patojenlerin birçok antibiyotiğe karşı dirençli oldukları tespit edilirken, Bacillus subtilisin bu patojenlerin neden olduğu enfeksiyonlara karşı önleyici probiyotik olarak kullanım olanağı önerilmektedir.

\section{Research Article}

$\begin{array}{ll}\text { Article History } & \\ \text { Received } & : 23.03 .2020 \\ \text { Accepted } & :\end{array}$

Antibiotic susceptibility

\author{
Keywords \\ Fish histopathology \\ Frigoribacterium faeni \\ Lactococcus garvieae \\ Bacillus subtilis
}

\section{Araştırma Makalesi}

Makale Tarihçesi

Geliş Tarihi : 23.03 .2020

Kabul Tarihi :

Anahtar Kelimeler

Balık histopatolojisi

Frigoribacterium faeni

Lactococcus garvieae

Bacillus subtilis

Antibiyotik duyarlılı̆g

To Cite: Akaylı T, Çanak Ö, Yardımcı RE, Ürkü Ç, Ökmen D 2020. A Mixed Frigoribacterium faeni and Lactococcus garvieae Infection in Cultured Rainbow Trout ( $O$. mykiss). KSU J. Agric Nat. 23 (6): 1569-1577. DOI: 10.18016/ksutarimdoga.vi.707820.

\section{INTRODUCTION}

Rainbow trout (Oncorhynchus mykiss) is among the major aquaculture species cultured in concrete ponds in land-based facilities, marine cages (Emre et al., 2007) and in dam-lakes in Turkey since 1960's (Akbulut et al., 2009). Total rainbow trout production amount of Turkey in inland water facilities was
101.761 tons in 2017 (TUİ, 2019). Bacterial origined fish diseases are among the main limiting factor in aquaculture (Austin and Austin, 2016). Previously motile Aeromonads (Muz et al., 1995), Streptococcus faecalis (Kan and Sarreyyüpoğlu, 2008) and Lactococcus garvieae (Türe et al., 2012; Öztürk et al., 2013; Balta and Balta, 2019) were recovered and identified as bacterial pathogens of rainbow trout 
cultured in dam lakes in Turkey.

Frigoribacterium faeni (fam: Microbacteriaceae) is a Gram-positive, bacterium mainly associated with plants and dust (Kampfer et al., 2000; Evtushenko and Takeuchi, 2006), which was also reported in the intestinal flora of healthy fish (Carbajal-Gonzalez et al., 2011; Urtubia et al., 2017). Previously, there is no report on the infection cases or pathogenicity of $F$. faeni in fish. Lactococcus garvieae (fam: Streptococcaceae) is an important Gram-positive (Teuber, 2009) pathogen of cultured rainbow trout. Lactococcosis is generally characterized by a type of bacterial hemorrhagic septicemia in fish and occurred in the increasing water temperature worldwide (Ksuda and Salati, 1999; Eyngor et al., 2004; Evans et al., 2009; Sharifiyazdi et al., 2010; Timur et al., 2011; Austin and Austin, 2016).

As a result of misuse of antibiotics, pathogens have developed resistance recently. Studies on environment-friendly prevention and treatment programs which eliminate the use of chemicals, are increasing in numbers (Austin and Austin, 2016). It is possible to prevent bacterial diseases in aquaculture by using probiotics that previously showed antagonism against pathogens including the members of Vibrio, Aeromonas and Streptococcus in-vitro (Gomez-Gil et al., 2000; Kumar et al., 2006; $\mathrm{Ng}$ et al., 2014; Mingmongkolchai and Panbangred, 2018).

The aim of this study was the diagnosis of the bacterial pathogens of moribund rainbow trout reared in a damlake cage farm located in the Black Sea Region of Turkey and determination of their antibiotic susceptibility and histopathological effects by using routine bacteriological and histopathological methods and molecular tools. Besides, possibility of the use of two probiotics against these pathogens for the prevention of further infections was investigated.

\section{MATERIAL and METHODS}

\section{Fish sampling:}

Fish samples were collected during a field sampling of a one-year monitoring study. A rainbow trout cageculture rainbow trout facility located in a dam lake in Black Sea Region of Turkey was visited in April of 2017. Total of 7 fish samples (100-250 g) of slowly swimming on the water surface with some clinical disease symptoms were anaesthetized with $2^{-}$ phenoxyethanol ( $1 \mathrm{ml} / \mathrm{l}$ in culture water) and examined clinically.

This study was conducted with the permission of Istanbul University Animal Experiments Local Ethical Committee (approved on 23.02.2017).

\section{Histopathological examination:}

Tissue samples (liver, kidney, spleen, heart, intestines, gills, skin, eyes) were directly fixed in \%10 formalin solution, processed with the routine laboratory methods, embedded in paraffin and $5 \mu \mathrm{m}$ slides were stained with hematoxylin \& eosin (Roberts, 2012).

\section{Bacteriological examination:}

Bacterial inoculations from the visceral organs (kidney, spleen and liver) were streaked onto TSA (Tryptic Soy Agar, Merck) and incubated at $20^{\circ} \mathrm{C}$ for $72 \mathrm{~h}$ (Roberts, 2012). Bacterial isolates were first identified by using biochemical profiles (Roberts, 2012; Austin and Austin, 2016). Later, DNA was isolated from bacterial isolates by using High Pure PCR Template Preparation Kit (Roche, Switzerland) and universal primers 27F (5'-AGA GTT TGA TCM TGG CTC AG-3') and 907R (5'-CCG TCA ATT CMT TTR AGT TT-3') were used for the amplification of $16 \mathrm{~S} / 23 \mathrm{~S}$ gene (Lane, 1991). 16s RNA sequencing from the PCR products were performed by Medsantek (İstanbulTurkey) and sequences were analyzed by using ClustalX 2.1 (Larkin et al., 2007) and BLASTN 2.2.20 (Zhang et al., 2000) algoritms on Bioedit v7.0.0 software (Hall, 1999). Besides, species-specific primers pLG-1 (5'-CATAACAATGAGAATCGC-3') and pLG-2 (5'-GCACCCTCGCGGGTTG- $3^{\prime}$ ) were used for the amplification of the $L$. garvieae-susceptible isolates (Zlotkin et al., 1998).

\section{Antibiotic susceptibility testing:}

Antibiotic susceptibility testing was performed using modified Kirby-Bauer disc diffusion method (Bhunia et al., 1988). Fresh cultures of bacterial isolates grown in Nutrient Broth were spread onto Mueller-Hinton agar; commercial antibiotic discs were placed and three replicates of petri dishes were incubated at $22^{\circ} \mathrm{C}$ for 48 $\mathrm{h}$ and inhibition zone diameters were measured. Tetracycline, kanamycin, florphenicol, furazolidone, sulphametaxozole trimethoprim, ciprofloxacin and enrofloxacin discs were used. Results were compared with the previous reports and NCCLS standards.

\section{Antagonism testing:}

Lyophilized Bacillus subtilis (ATCC 6633TM) and Lactobacillus rhamnosus (ATCC 7469TM) were used as probiotic candidates and fresh cultures of them were prepared by streaking onto TSA (Tryptic soy agar) and incubated at $22{ }^{\circ} \mathrm{C}$ for $48 \mathrm{~h}$. Modified Kirby-Bauer disc diffusion method was used for the determination of antagonism against pathogenic bacteria (Bhunia et al., 1988). Briefly, $200 \mu \mathrm{l}$ of fresh cultures of pathogenic bacteria growth in Nutrient Broth were streaked onto TSA medium to cover all the surface. Later, blank antibiotic susceptibility paper-discs were dipped into fresh cultures of probiotic-candidates growth in Nutrient Broth and placed onto TSA medium. Three replicates of TSA medium containing petri dishes were incubated at $22{ }^{\circ} \mathrm{C}$ for $48 \mathrm{~h}$ and inhibition zone diameters were measured. 


\section{RESULTS}

In this study, infections caused by $F$. faeni and $L$. garvieae in rainbow trout cultured in a dam lake was diagnosed by using bacteriologic and molecular methods, pathological effects of the disease in the infected fish tissues were demonstrated, antibiotics which can be used for the treatment were determined and a possibility of the use of a probiotic bacterial species was proposed.

Fish samples examined in this study were chosen from the individuals that are swimming slowly on the water surface which are lethargic with loss of appetite. Moribund fish samples showed mass skin pigmentation, darkening of the skin, loss of scales, melting of the dorsal fin and erosion in the upper jaw (Figure 1a). Mass hemorrhages in the eyes and severe exophthalmos in some samples were observed (Figure 1a). Internally, hemorrhagic lesions on the anemic liver, splenomegaly and enlargement of the bile duct was observed (Figure 1b). Also, accumulation of a bloody fluid in the peritoneal cavity was noted in some fish samples (Figure 1b).

Anemia, slight atrophy, cell necrosis and hyperemia were observed in the liver (Figure 2a). Hemosiderin accumulation, slight liquefactive necrosis of the interrenal haemopoietic tissue and tubular deformation were observed in the kidney (Figure 2b). Slight necrosis and depletion of the pulps were noted in the spleen where the hemosiderin accumulation was rarely seen (Figure 2c). Epithelial and connective tissues were weakened in the primer and secondary lamellae of the gills (Figure $2 \mathrm{~d}$ ). Also, there were mass hyperemia in the supportive tissue of the exophthalmic eyes and deformation of the microvilli were observed in the intestines.

Two types of colonies were recovered from the visceral organs of fish samples; creamy-white colonies with a diameter of 1-2 mm (Figure 3a) and yellowish colonies with a diameter of 3-4 mm (Figure 3b). Creamy colonies that consist of Gram-positive fermentative non-motile cocci-shapes cells in short chains were oxidase, catalase, lactose and VP negative; MR and arginine positive and $\alpha$-hameolytic on blood agar and hence they were identified as Lactococcus sp. Yellowish colonies that consist of Gram-positive motile cocci-shapes cells in small clusters were oxidase, MR, VP and indole negative; catalase positive and possessed variable results in citrate and nitrate tests and hence they were identified as Frigoribacterium sp. Results of the conventional bacteriologic tests were shown in Table 1. An 880 bp region was obtained with the PCR amplification conducted with the universal primers $27 \mathrm{~F}$ and $907 \mathrm{R}$. The obtained $16 \mathrm{~S}$ RNA sequence analysis was processed in the BioEdit software and after the GeneBank nucleotide blasting,
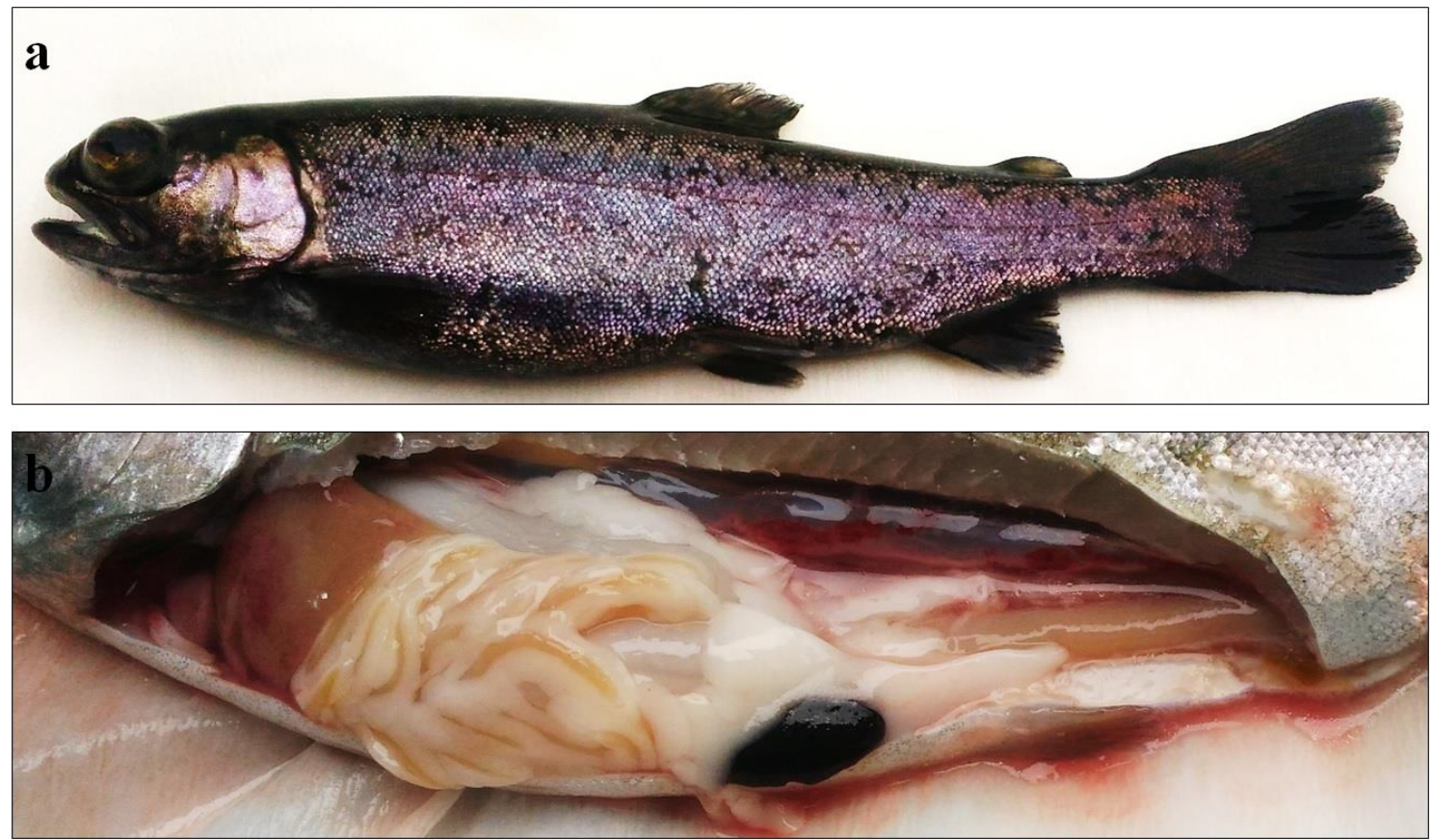

Figure 1. a) Mass skin pigmentation, darkening of the skin, fin and jaw erosion and severe exophthalmos in the moribund fish samples. b) Hemorrhagic lesions on the anemic liver, splenomegaly and accumulation of a bloody fluid in the peritoneal cavity of moribund fish samples.

Şekil 1. a) Hasta balık numunelerinde yoğun deri pigmentasyonu, deri renginde koyulaşma, yüzgeç ve çene erozyonu ve ileri seviyede ekzoftalmus. b) Hasta balık numunelerinde anemik karaciğer üzerinde hemorajik lezyonlar, dalakta büyüme ve peritoneal boşlukta kanlı sıvı birikimi. 

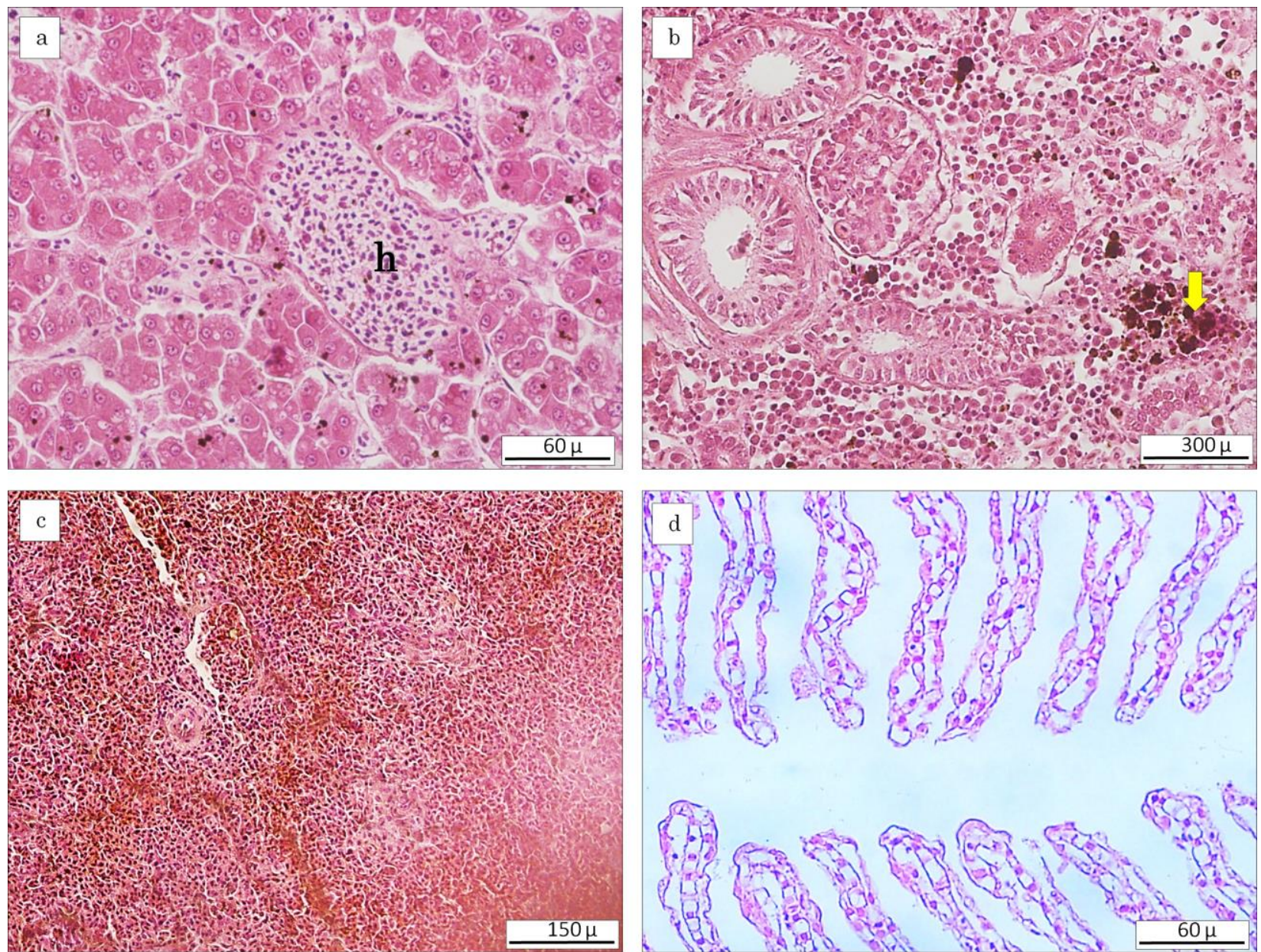

Figure 2. Histopathological changes observed in the moribund fish samples a) Atrophic hepatic cells and hyperemia [h] in liver b) Tubular degeneration and hemosiderin accumulation [arrowed] in kidney c) necrosis and depletion of the pulps in spleen d) Weakened secondary gill filaments. All hematoxylin \& eosin.

Şekil 2. Hasta balık numunelerinde gözlemlenen histopatolojik değisimler a) karaciğerde atrofik hepatik hücreler ve hiperemi (h) b) böbrekte tübüler dejenerasyon ce hemosiderin birikimi (okla gösterilmiştir) c) dalakta nekroz e pulpalarda boşalma d) zayıflamış sekonder solungaç filamentleri. Tümü hematoksilen\&eozin ile boyanmiştır.
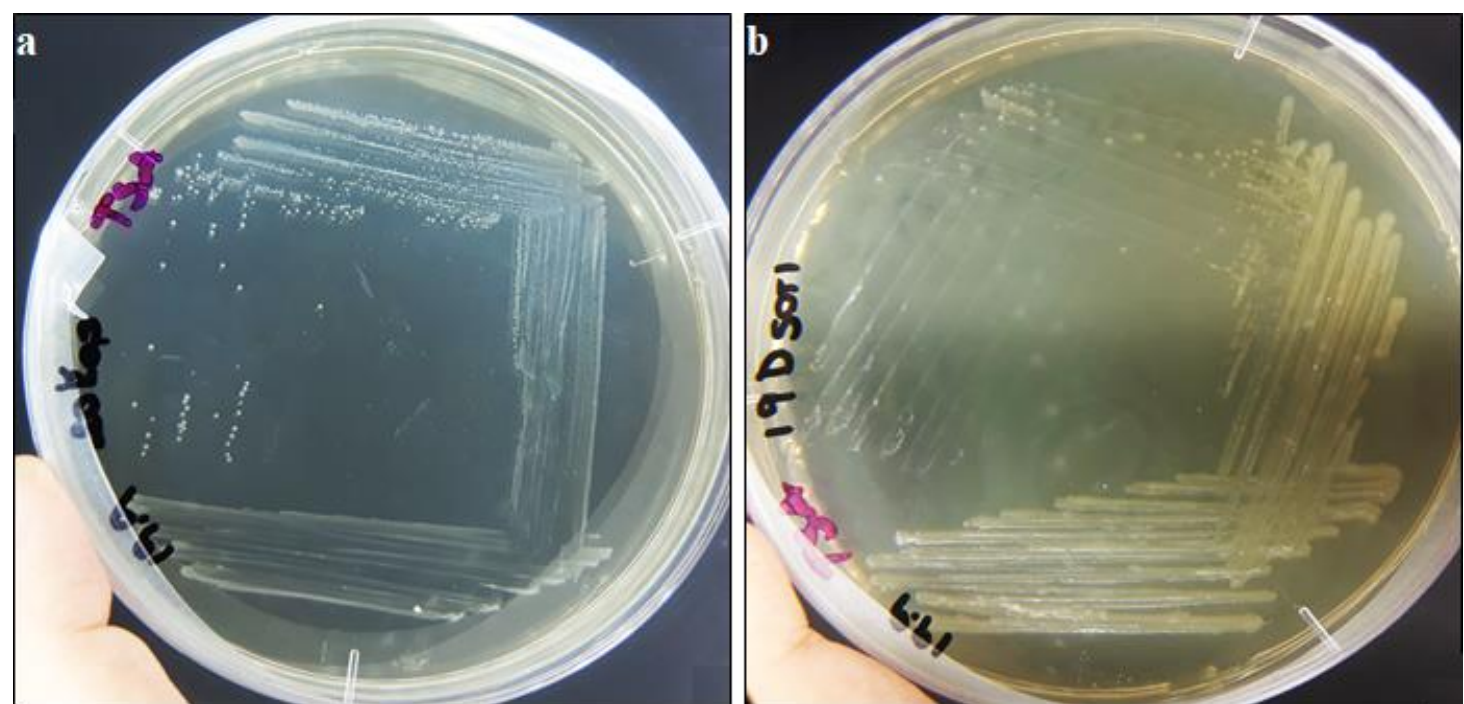

Figure 3. a) Creamy-white L. garvieae colonies on TSA b) Yellowish F. faeni colonies on TSA

Şekil 3. a) TSA besiyeri üzerinde krem-beyaz renkli L. garvieae kolonileri b) TSA besiyeri üzerinde sarımsı F. faeni kolonileri 
Table 1. Biochemical characteristics of bacterial isolates Cizelge 1. Bakteri izolatlarının biyokimyasal özellikleri

\begin{tabular}{lcc} 
& Lactococcus sp. & Frigoribacterium $s p$. \\
Gram & $n=21$ & $n=12$ \\
Motility & + & + \\
O/F & - & + \\
Catalase & $\mathrm{F}$ & $\mathrm{F}$ \\
Oxidase & - & + \\
Indole & - & - \\
MR & $+/-$ & - \\
VP & + & - \\
Nitrate & $+/-$ & $+/-$ \\
Citrate & - & $+/-$ \\
Acid production from & - & \\
Galactose & + & + \\
Lactose & - & - \\
Rhamnose & $+/-$ & + \\
Sucrose & + & + \\
Maltose & + & + \\
Sorbitol & - & + \\
Inositol & $+/-$ & - \\
Fructose & + & + \\
\hline
\end{tabular}

+ : positive reaction, ${ }^{-}$: negative reaction $\mathrm{F}$ : fermentative

our isolates that were identified as Lactococcus sp. showed $100 \%$ similarity with the previous $L$. garvieae sequences. Also, our isolates that were identified as Frigoribacterium sp. showed 99\% similarity with Frigoribacterium faeni. Besides, in the other PCR amplification, a $1100 \mathrm{bp}$ region was obtained with the PCR amplification conducted with the $L$. garvieae specific primers $\mathrm{pLG}-1$ and $\mathrm{pLG}-2$.

$F$. faeni was found to be sensitive or semi-sensitive against all antibiotics used (Table 2). In contrast, as a well-known fish pathogen, L. garvieae isolates were found to be resistant against kanamycin, florphenicol, and sulphametaxozole trimethoprim. They were also semi-resistant against furazolidone, ciprofloxacin and enrofloxacin, but only sensitive to tetracycline (Table 2).

Table 2. Antibiotic susceptibilities of the isolated pathogens

Cizelge 2. İole edilen patojenlerin antibiyotik duyarlılıkları

\begin{tabular}{lcc} 
& $\boldsymbol{F}$. faeni & L. garvieae \\
Tetracycline (T30) & 4,2 (S) & 2,8 (S) \\
Kanamycin (K30) & $1,5(\mathrm{SR})$ & $\mathrm{R}$ \\
Florphenicol (FFC30) & 3,2 (S) & $\mathrm{R}$ \\
Sulphametaxozole & $2,5(\mathrm{~S})$ & $\mathrm{R}$ \\
Trimethoprim (SXT25) & & \\
Furazolidone (FX100) & 1,8 (SR) & 1,4 (SR) \\
Ciprofloxacin (CIP1) & 1,8 (SR) & $1,2(\mathrm{SR})$ \\
Enrofloxacin (ENR5) & 2,2 (SR) & 1,8 (SR) \\
\hline
\end{tabular}

(zone diameters in $\mathrm{cm}$ ) S: Sensitive; SR: Semi-resistant; R: resistant (no inhibition zone)
Among the probiotic-candidate bacteria tested, Bacillus subtilis showed weak antagonistic effect against the secondary pathogen $F$. faeni with a mean inhibition zone diameter of $1.5 \mathrm{~cm}$ (Figure 4a). Also, this species showed strong positive antagonistic effect against the main pathogen $L$. garvieae isolates recovered from internal organs the diseased fish samples with inhibition zone diameters between 3.0 and $4.3 \mathrm{~cm}$ (Figure 4b). In contrast, L. rhamnosus showed no antagonistic effect against both pathogens in vitro.

\section{DISCUSSION}

Fish samples showed similar clinical external and internal symptoms such as darkening of the skin, hemorrhages, and splenomegaly as reported in previous lactococcosis cases (Kang et al., 2004; Altun et al., 2005; Vendrell et al., 2006; Özer et al., 2008; Avc1 et al., 2010; Öztürk et al., 2013; Avc1 et al., 2014; Didinen et al., 2014; Ürkü and Timur, 2014; Balta and Balta, 2019) with slight variations. As an expectation, similar symptoms in the eyes such as exophthalmos, hemorrhages and opacification of the cornea was observed in the fish samples but not the loss of eyes as reported by Timur et al., (2011) and Öztürk et al. (2013). Also lesions on the skin reported by Öztürk et al. (2013) were not observed in our fish samples.

Similar to the previous lactococcosis cases, fish samples showed various histopathological symptoms such as tubular degeneration, periglomerular edema and melanomacrophage centers in the kidney (Altun et al., 2005; Timur et al., 2011; Avc1 et al., 2014; Didinen et al., 2014; Ürkü and Timur 2014). But, liquefactive necrosis in the liver and kidney that were demonstrated previously (Timur et al., 2011; Ürkü and Timur, 2014; Korun et al., 2017) were in a more advanced stage than our samples.

Many species of the genus Frigoribacterium (Microbacteriaceae family) were previously thought to be pshcyrophilic bacteria that can be isolated from air and soil (Kampfer et al., 2000; Evtushenko and Takeuchi, 2006). Carbajal-Gonzalez et al. (2011) and Urtubia et al. (2017) recovered Frigoribacterium sp. from the intestines of healthy fish. With this study, a bacterium that is identified as $F$. faeni according to the biochemical and molecular results, was recovered and identified for the first time from the visceral organs of moribund fish samples.

Lactococcosis is a well-known disease of rainbow trout worldwide (Austin and Austin, 2016) and previously reported in Turkish trout culture sector in warm seasons (Diler et al., 2002; Altun et al., 2005, Kav and Erganis, 2007; Akşit and Kum, 2008; Avcı et al., 2010; Timur et al., 2011; Didinen et al., 2014; Durmaz and Kılıçoğlu, 2015; Korun et al., 2017; Balta and Balta, 2019). In most of the reports on Lactococcosis cases of 
cultured rainbow trout in Turkey, L. garvieae was identified as disease agent in pure infections. Previously, only Tanrıkul and Gültepe (2011) reported a mixed lactococcosis infection of rainbow trout in which Vibrio anguillarum has involved. Similarly, a mixed bacterial infection case that $F$. faeni and $L$. garvieae has involved was diagnosed in our study. Öztürk et al. (2013) and Balta and Balta (2019) described rainbow trout lactococcosis cases in dam lakes located in the Blacksea Region in April and May similar to our study with mostly similar clinical signs. L. garvieae isolates recovered in this study showed a similar biochemical profile with the previous fish lactococcosis reports (Ringo and Gatesoupe, 1998; Vendrell et al., 2006) and this identification was confirmed with molecular identification (Zlotkin et al., 1998; Altun et al, 2013; Didinen et al., 2014; Korun et al., 2017; Balta and Balta, 2019).

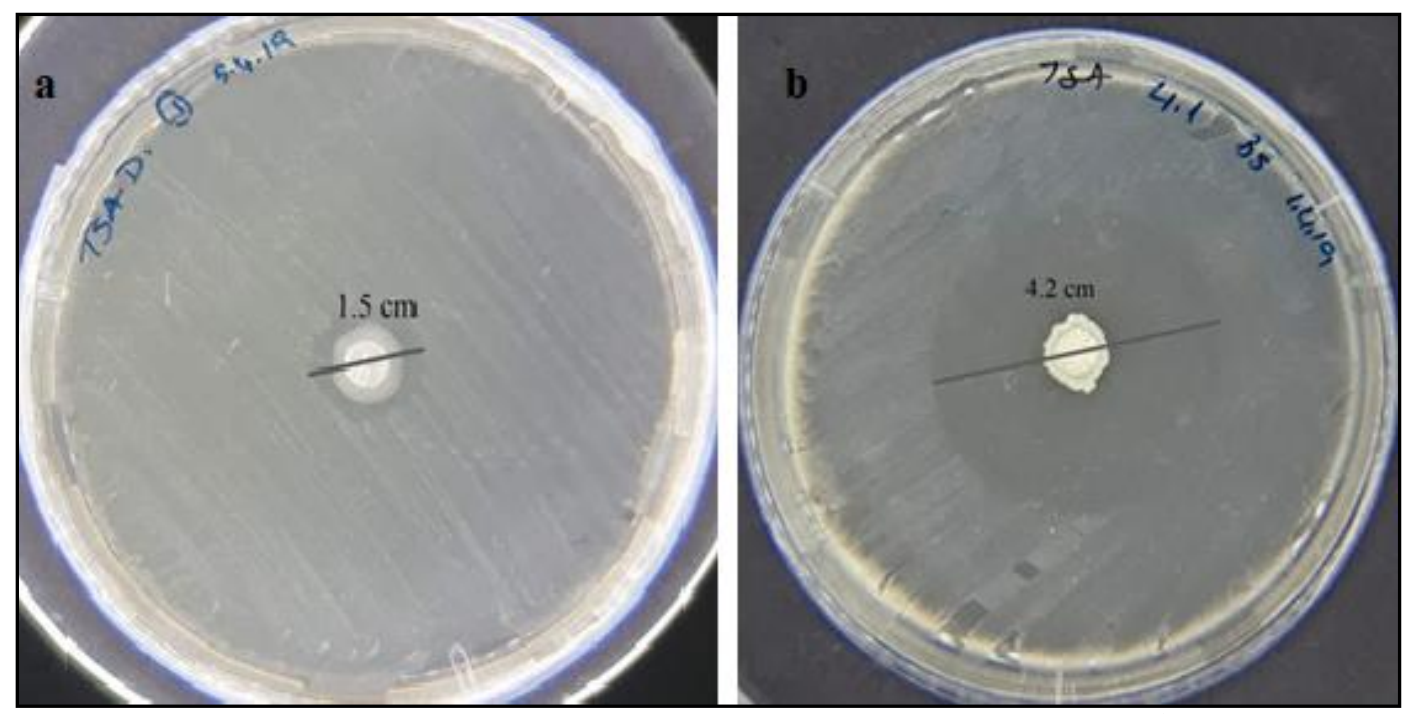

Figure 4. Antagonistic effect of B. subtilis against isolated pathogens a) Weak positive result against F. faeni Strong positive result against L. garvieae.

Şekil 4. B. subtilis'in izole edilen patojenlere karşı antagonistik etkisi. a) F. faeni'ye karşı zayıf antagonistik etki. b) L. garvieae'ye karşı kuvvetli antagonistik etki.

Use of improper antibiotic substance may be ineffective for disease treatment and hence causes economical losses. Also, excessive or inadequate use of the correct antibiotic may be again ineffective for treatment and may cause antibiotic resistance among the potentially pathogenic bacteria in the production site (Austin and Austin, 2016). As a new fish pathogen that was not treated with the antibiotics previously, Previously, L. garvieae was reported to be resistant to kanamycin (Kubilay et al., 2005; Öztürk et al., 2013; Didinen et al., 2014; Teker et al.,2018), florphenicol (Altun et al., 2013), and sulphametaxozoletrimethoprim (Kubilay et al., 2005; Kav and Erganis, 2007; Altun et al., 2013; Durmaz and Kılıçoğlu, 2015; Balta and Balta, 2019) and sensitive or semisensitive to furazolidone (Chang et al., 2002), ciprofloxacin (Akşit and Kum, 2008, Kav and Erganis, 2007; Raissy and Moumeni, 2016), enrofloxacin (Kubilay et al., 2005; Akşit and Kum, 2008; Kav and Erganis, 2007; Durmaz and Kılıçoğlu, 2013; Öztürk et al., 2013; Balta and Balta, 2019) and tetracycline (Kubilay et al., 2005; Öztürk et al., 2013). Also previously different susceptibility results were achieved for kanamycine (Durmaz and Kılı̧̧oğlu, 2013), florphenicol (Öztürk et al., 2013; Teker et al., 2018; Balta and Balta, 2019) sulphametaxzozole trimethoprim (Raissy and
Moumeni, 2016; Teker et al., 2018), ciprofloxacin (Kubilay et al., 2005; Teker et al., 2018) enrofloxacin (Teker et al., 2018) and tetracycline (Didinen et al., 2014; Raissy and Moumeni, 2016).

Due to the problems in antibiotic treatment in term of selection as described above, recent research on fish diseases has aimed to improve diagnostics by use of sensitive and specific molecular methods and disease control especially by vaccination, probiotics and plant products (Austin and Austin, 2016). Various Lactic acid bacteria such as Lactobacillus species and members of the genus Bacillus, especially B. subtilis were determined to have antagonistic effect against many fish pathogens including Aeromonas hydrophila (Kumar et al., 2006), Yersinia ruckeri (Raida et al., 2003) and Streptococcus agalactiae (Ng et al., 2014). Lactocbacillus rhamnosus was used as a probiotic bacterium especially against Gram-negative pathogens of marine fishes (Gomez-Gil et al., 2000; Ashraf, 2000; Katırcıoğlu, 2001) but it was insufficient to inhibit Gram-positive pathogens (Ringo and Gatesoupe, 1998; Burr and Gathlin, 2005). In this study, B. subtilis was determined as a promising probiotic-candidate with in-vitro studies for the prevention of lactococcosis in rainbow trout. Long-term and repetitive use of this probiotic-candidate 
bacterium in the consecutive production seasons, would possibly increase the antagonistic effect against this pathogen and protection.

In conclusion, the results of this study showed that $F$. faeni and L. garvieae are important fish pathogens affecting rainbow trout culture with important clinical and histopathological symptoms. Since these bacteria causes mortalities and can raise resistance against some of the most popular antibiotics used in aquaculture, protection via vaccines and/or probiotics is of crucial importance. In-vitro results of this study showed that, $B$. subtilis is a promising probioticcandidate for the protection of rainbow trout in aquaculture from bacterial infections.

\section{ACKNOWLEDGEMENTS}

This study was approved by the Animal Experiments Local Ethics Committee of Istanbul University. This study was supported by Istanbul University Research Projects coordination unit with the project number: FBA-2018-28476. As a part of this long-term project, MSc. thesis of Dilek OKMEN from Istanbul University Institute of Science was also supported financially. The authors also would like to thank the staff of the fish farms for their valuable helps during field sampling.

\section{Statement Contribution of the Authors}

Authors declares the contribution of the authors is equal.

\section{Statement of Conflict of Interest}

Authors have declared no conflict of interest.

\section{REFERENCES}

Akbulut B, Kurtoğlu IZ, Üstündağ E, Aksungur M 2009. Karadeniz Bölgesi'nde Balık Yetiştiriciliğinin Tarihsel Gelişimi ve Gelecek Projeksiyonu. Journal of Fisheries Science, 3(2):76- 85.

Akşit D, Kum C 2008. Gökkuşağı alabalıkları (Oncorhynchus mykiss, W. 1792)'nda Sik Görülen Patojen Mikroorganizmalarin Tespiti ve Antibiyotik Duyarlılık Düzeylerinin Belirlenmesi. Van Vet J, 19(1):1-7.

Altun S, Diler A, Diler Ö, Başak K, Işıklı B 2005. Histopathology of Streptococcosis in Rainbow Trout. B Eur Assoc Fish Pat, 25(3):131-135.

Altun S, Onuk EE, Çiftçi A, Büyükekiz AG, Duman M 2013. Phenotypic, Genotypic Characterisation and Antimicrobial Susceptibility Determination of Lactococcus garvieae Strains. Kafkas Univ Vet Fak, 19(3):375-381.

Ashraf A 2000. Probiotics in Fish Farming-Evaluation of a Candidate Bacterial Mixture, Licentiate thesis, University of Umea.

Austin B, Austin DA 2016. Bacterial Fish Pathogens, Diseases of Farmed and Wild Fish, 6 ${ }^{\text {th }}$ Edition.
Springer Publishing, Dordrecht, 978-3-319-326740. Pages: 41-48

Avcı H, Aydoğan A, Tanrıkul TT, Birincioğlu SS 2010. Pathological and Microbiological Investigations in Rainbow Trout (Oncorhynchus mykiss) Naturally Infected with Lactococcus garvieae. Kafkas Univ Vet Fak, 16:313-318.

Avcı H, Birincioğlu SS, Tanrıkul TT, Epikmen ET, Metin N, Avsever ML 2014. Experimental Lactococcus garvieae Infection in Rainbow Trout, Oncorhynchus mykiss, Walbaum 1792: a Comparative Histopathological and Immunohistochemical Study. J Fish Dis, 37(5):481-495.

Balta F, Balta ZD 2019. The Isolation of Lactococcus garvieae from Eyes of Diseased Rainbow Trout (Oncorhynchus mykiss) with Exopthalmia. Journal of Anatolian Environmental and Animal Sciences, 4(1):27-33.

Bhunia AK, Johnson MC, Ray B 1988. Purification, Characterization and Antimicrobial Spectrum of Bacteriocin Produced by Pediococcus acidilactici. J Appl Microbiol, 65:261-268.

Burr G, Gathlin D 2005. Microbial Ecology of the Gastrointestinal Tract of Fish and the Potential Application of Prebiotics and Probiotics in Finfish Aquaculture. J World Aquacult Soc, 36:425- 436.

Carbajal-Gonzalez MT, Fregeneda-Grandes JM, Suarez-Ramos S, Cadenas FR, Aller-Gancedo JM 2011. Bacterial Skin Flora Variation and invitro Inhibitory Activity Against Saprolegnia parasitica in Brown and Rainbow Trout. Dis Aquat Organ, 96:125-135.

Chang PH, Lin CW, Lee YC 2002. Lactococcus garvieae Infection of Cultured Rainbow Trout, Oncorhynchus mykiss, in Taiwan and Associated Biophysical Characteristics and Histopathology. B Eur Assoc Fish Pat, 22(5):319-327.

Diler Ö, Altun S, Adiloğlu A, Kubilay A, Işıklı B 2002. First Occurrence of Streptococcosis Affecting Farmed Rainbow Trout in Turkey. B Eur Assoc Fish Pat, 22(1):21-26.

Didinen BI, Yardımcı B, Onuk EE, Metin S, Yıldırım P 2014. Naturally Lactococcus garvieae Infection in Rainbow Trout (Oncorhyncus mykiss Walbaum, 1792): New Histopathological Observations, Phenotypic and Molecular Identification. Rev Med Vet-Toulouse, 165:12-19.

Durmaz Y, Kılıçoğlu Y 2015. Bir Alabalık Çiftliğinde Doğal Enfekte Gökkuşağı Alabalıklarından (Oncorhynchus mykiss Walbaum, 1792) Lactococcus garvieae'nin Kültür ve PCR ile Saptanması ve Etkenin Antibiyotik Duyarlılık Profillerinin Belirlenmesi. Atatürk University J Vet Sci, 10(2):109-115.

Emre Y, Okumuş I, Maltaş Ö 2007. Trout Farming In: Marine Aquaculture in Turkey, TUDAV, İstanbul, 978-975-8825-18-9.

Evans JJ, Klesius PH, Schoemaker CA 2009. First 
Isolation and Characterization of Lactococcus garvieae from Brazilian Nile Tilapia, Oreochromis niloticus (L.) and Pintado, Pseudoplathystoma corruscans. J Fish Dis, 32:943-951.

Evtushenko LI, Takeuchi M 2006. The Family Microbacteriaceae Chapter 1.1.28 In: The Prokaryotes, Vol 3. Archaea. Bacteria: Firmicutes, Actinomycetes. Springer, 978-0387-25493-7. Pages 1020-1098.

Eyngor M, Zlotkin A, Ghittino C, Prearo M, Douet DG, Chikmonczyk S, Eldar A 2004. Clonality and Diversity of the Fish Pathogen Lactococcus garvieae in Mediterranean Countries. Appl Environ Microb, 70:5132-5137.

Gomez-Gil B, Roque A, Turnbull JF 2000. The Use and Selection of Probiotic Bacteria for Use in the Culture of Larval Aquatic Organisms. Aquacult, 191:259-270.

Hall TA 1999. BioEdit: a User-Friendly Biological Sequence Alignment Editor and Analysis Program for Windows 95/98/NT. Nucleic Acids Symposium Series, 95-98.

Kampfer P, Rainey FA, Andersson MA, Nurmiaho Lassila EL, Ulrych U, Busse HJ, Weiss N, Mikkola R, Salkinoja-Salonen M 2000. Frigoribacterium faeni gen. nov., so. nov., a Novel Psychrophilic Genus of the Family Microbacteriaceae, Int J Syst Evol Micr, 50:355-363.

Kan Nİ, Sarıeyyüpoğlu M 2008. Elâzığ Şehir Kanalizasyonunun Keban Baraj Gölü’ne Döküldüğü Bölgeden Yakalanan Balıklarda Streptokokus'ların Araştırılması. Fırat Üniv Fen Bil Derg, 20(2):271-277.

Kang S, Shin G, Shin Y, Kim Y, Yang H, Lee E, Huh N, Ju O, Jung T 2004. Experimental Evaluation of Pathogenicity of Lactococcus garvieae in Black Rockfish (Sebastes schlegeli). J Vet Sci, 5(4):387390.

Katırcıŏglu H 2001. Gökkuşağı Alabalığı ve Aynalı Sazandan Izole Edilen Laktik Asit Bakterilerinin Metabolik ve Antimikrobiyal Aktivitelerinin Incelenmesi. Gazi Üniversitesi Fen Bilimleri Enstitüsü Biyoloji Ana Bilim Dalı, Doktora tezi, 139 sy, Ankara.

Kav K, Erganiş O 2007. Konya Bölgesinde Bulunan Gökkuşağı Alabalığı (Oncorhynchus mykiss) Çiftliklerinden Lactococcus garvieae Izolasyonu, Identifikasyonu ve Fenotipik Özelliklerinin Belirlenmesi. Ataturk Univ Vet Bil. Derg, 23(1):717.

Korun J, Timur G, Yardımcı RE, Balcı BA 2017. Histopathological Changes of Rainbow Trout after Experimental Infection with Lactococcus garvieae. J Adv. Vetbio Sci Tech, 2(3):12-20.

Ksuda R, Salati F 1999. Enterecoccus seriolicida and Streptococcus iniae, In: Fish diseases and disorders, Woo P.T.K, Bruno, D.W. (ed.), Vol:3, CABI Publishing. Pages: 303-317.
Kubilay A, Altun S, Uluköy G, Diler Ö 2005. Lactococcus garvieae Suşlarının Antimikrobiyal Duyarlılıklarmın Belirlenmesi. Süleyman Demirel Üniv Eğirdir Su Ürün Fak Derg, 1(1):39-48.

Kumar R, Mukherjee SC, Prasad KP, Pal AK 2006. Evaluation of Bacillus subtilis as a Probiotic to Indian Major Carp Labeo rohita (Ham.). Aquac Res, 37(12):1215-1221.

Lane DJ 1991. 16S/23S rRNA sequencing, Nucleic acid techniques in bacterial systematics, Chichester: John Wiley \& Sons.

Larkin MA, Blackshields G, Brown N, Chenna R, Mcgettigan PA, Mcwilliam H, Valentin F, Wallace IM, Wilm A, Lopez R 2007. Clustal W and Clustal $\mathrm{X}$ version 2.0. J Bioinform, 23:2947-2948.

Mingmongkolchai S, Panbangred W 2018. Bacillus Probiotics: an Alternative to Antibiotics for Livestock Production. J Appl Microbiol, 124:13341346.

Muz A, Sarıeyyüpoğlu M, Ertaş HB, Şimşek A 1995. Keban Baraj Gölü’nden Yakalanan Bazı Balıkların Aerobik ve Mikroaerofilik Bakteriler Yönünden Incelenmesi. Fırat Üniv Sağllk Bilim Derg, 9(2):212-219.

Ng WK, Kim YC, Romano N, Koh CB, Yang SY 2014. Effects of Dietary Probiotics on the Growth and Feeding Efficiency of Red Hybrid Tilapia, Oreochromis sp., and Subsequent Resistance to Streptococcus agalactiae. J Appl Aquac, 26(1):2231.

Özer S, Bulduklu PS, Dönmez E 2008. Mersin Ilinde Yetiştiriciliği Yapılan Gökkuşağı Alabalıklarında (Oncorhynchus mykiss, Walbaum) Streptokokkozis Varlığı. Journal of fisheriessciences.com, 2(3):272283.

Öztürk T, Didinen BI, Doğan G, Özer A, Bircan R 2013. Lactococcosis in Rainbow Trout (Oncorhynchus mykiss, Walbaum, 1792) in the Middle Black Sea Region in Turkey and Antimicrobial Susceptibility of the Aetiological Agent, Lactococcus garvieae. Etlik Vet Mikrobiyol Derg, 24:7-12.

Raida MK, Larsen JL, Nielsen ME, Buchmann K 2003. Enhanced Resistance of Rainbow Trout, (Oncorhynchus mykiss, Walbaum), against Yersinia ruckeri Challenge Following Oral Administration of Bacillus subtilis and $B$. licheniformis (BioPlus2B). J Fish Dis, 26:495-498.

Raissy M, Moumeni M 2016. Detection of Antibiotic Resistance Genes in Some Lactococcus garvieae Strains Isolated from Infected Rainbow Trout. Iran J Fish Sci, 15(1):221-229.

Ringo E, Gatesoupe FJ 1998. Lactic Acid Bacteria in Fish: a Review. Aquacult, 160:177-203.

Roberts RJ 2012. Fish Pathology, $4^{\text {th }}$ Edition, WileyBlackwell, UK., 978-1-4443-32827. Pages: 439-565.

Sharifiyazdi H, Mosttafa A, Tabatabaei M, Zadeh SMM 2010. Isolation and Characterization of Lactococcus garvieae from Diseased Rainbow Trout 
(Oncorhynchus mykiss, Walbaum) Cultured in Iran. Iran J Vet Res, 11(4):342-350.

Tanrıkul TT, Gültepe N 2011. Mix Infections of Rainbow Trout (Oncorhynchus mykiss Walbaum): Lactococcus garvieae and Vibrio anguillarum O1. J Anim Vet Adv, 10(8):1019-1023.

Teker T, Albayrak G, Akaylı T, Ürkü Ç 2018. Detection of Haemolysin Genes as Genetic Determinants of Virulence in Lactococcus garvieae. Turk J Fish Aquat Sci, 19(7):625-634.

Teuber, M., (2009). Lactococcus, In: Bergey's manual of systematics bacteriology Vol III, Parte, A.C (ed.), $2^{\text {nd }}$ Ed., Springer Dordrecht Heidelberg London New York. Pages: 711-722.

Timur G, Yardımcı RE, Ürkü Ç, Çanak Ö 2011. Marmara Bölgesi Kültür Gökkuşağ̀ Alabalıklarında (Oncorhynchus mykiss, L.) Lactococcosis'in Bakteriyolojik ve Histopatolojik Metodlarla Teşhisi. İstanbul Üniv Su Ürün Derg, 26:63-81.

TUIK, 2019, Kültür Balıkları Üretim Miktarı, http://tuik.gov.tr/PreTablo.do?alt_id=1005, [Ziyaret tarihi: 6 Mayis 2019].

Türe M, Altınok İ, Işıdan H, Savaş H, Kutlu İ 2012. PFGE Metodu Kullanılarak Lactoccoccus garvieae'nin Genetik Çeşitliliğinin ve Yayılımının Belirlenmesi, TAGEM Proje Sonuç Raporu. Su Ürünleri Merkez Araştırma Enstitüsü, Trabzon.

Urtubia R, Gallardo P, Cardenas CA, Lavin P, Gonzalez-Aravena M 2017. First Characterization of Gastrointestinal Culturable Bacteria of Patagonian Toothfish Dissosstichus eleginoides (Nototheniidae). Rev Biol Mar Oceanog, 52(2):399404.

Ürkü Ç, Timur G 2014. A Comparative Study of Detection Methods for Lactococcus garvieae in Experimentally Infected Rainbow Trout (Oncorhynchus mykiss, W.). Isr J Aquacult-Bamid, 66, 10 pages.

Vendrell D, Balcazar JL, Zarzuela IR, DeBlas I, Girones O, Muzquiz JL 2006. Lactococcus garvieae in Fish: a review. Comp Immunol Microbiol Infect Dis, 29:177-198.

Zhang Z, Schwartz S, Wagner L, Miller W 2000. A Greedy Algorithm for Aligning DNA Sequences. J Comput Biol, 7:203-214.

Zlotkin A, Eldar A, Ghittino C, Bercovier H 1998. Identification of Lactococcus garvieae by PCR. J Clin Microbiol, 36(4):983-985. 